\title{
The doctrine of theosis and the reality of purpose: exploring the convergence between deification and organismic teleology
}

Mikael Leidenhag

\begin{tabular}{|c|c|}
\hline Date of deposit & 24 June 2020 \\
\hline Document version & Author's accepted manuscript \\
\hline Access rights & $\begin{array}{l}\text { Copyright (c) Toronto Journal of Theology. This work is made } \\
\text { available online in accordance with the publisher's policies. This is } \\
\text { the author created, accepted version manuscript following peer } \\
\text { review and may differ slightly from the final published version. }\end{array}$ \\
\hline $\begin{array}{l}\text { Citation for } \\
\text { published version }\end{array}$ & $\begin{array}{l}\text { Leidenhag, M. (2021). The doctrine of theosis and the reality of } \\
\text { purpose: exploring the convergence between deification and } \\
\text { organismic teleology. Toronto Journal of Theology, 37(2), 198- } \\
209 .\end{array}$ \\
\hline $\begin{array}{l}\text { Link to published } \\
\text { version }\end{array}$ & https://doi.org/10.3138/tjt-2020-0110 \\
\hline
\end{tabular}

Full metadata for this item is available in St Andrews Research

Repository at: https://research-repository.st-andrews.ac.uk/

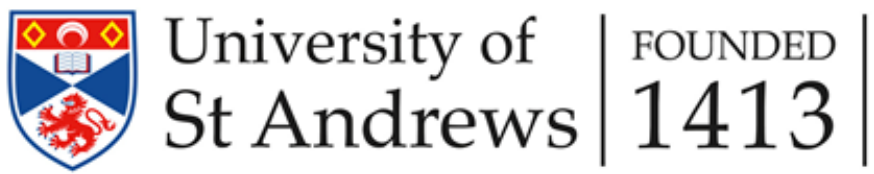




\section{The Doctrine of Theosis and the Reality of Purpose: Exploring the Convergence between Deification and Organismic Teleology}

The rich theological doctrine of theosis situates human personhood in the light of God's purpose for humanity. It brings together soteriology and eschatology by emphasising humans as potential participators in the divine life, and it signifies a theocentric basis of human becoming. From the perspective of the Eastern Orthodox concept of theosis, human nature cannot be explicated solely through static properties but it must be situated relationally in terms of God's redemptive plan for humanity and creation. The logic of this theological framework stresses that what we are is intrinsically tied up with what we will become. A doctrine of deification emphasises the ongoing transformation of humanity and it is in union and communion with God that we heal our incomplete state and become fully human, thereby fulfilling the divine purpose for our existence. Hence, "What God is in nature, it is commonly argued and debated in the Eastern Orthodox tradition, humanity can become by participation, first in the image and then in likeness, following the prototype of Christ." "To be deified, however, is not to become less human and thus more divine, "but more human by becoming more divine to fulfill the telos of that God had intended for humanity through relationship with him." ${ }^{2}$ The Eastern Orthodox conception of theosis entails a profoundly teleological conception of human nature: a full account of the human person is only construable in light of the divine telos for humanity and creaturely participation in God's redemptive intent for creation.

Ever since Charles Darwin's On the Origin of Species and the rise of mechanistic explanations and ontologies, the notion of teleology has been seen as scientifically obsolete, vacuous, and even occult. Teleological language shows up in different types of discourses, including scientific ones, but is either deemed as heuristic fiction or simply eliminable. In this way, there seems to be an apparent metaphysical tension between the purposeful view of human nature and creation as depicted in theosis and the anti-teleological views of some prominent biologists.

\footnotetext{
${ }^{1}$ Michael J. Christensen, "The Promise, Process, and Problem of Theosis," in Partakers of the Divine Nature: The History and Development of Deification in the Christian Traditions, eds. Michael J. Christensen and Jeffrey A. Wittung (Grand Rapids: Rosemont Publishing and Printing Corp., 2007), 25.

2 Ben C. Blackwell and Kris A. Miller, "Theosis and Theological Anthropology," in The Ashgate Research Companion to Theological Anthropology, eds. Joshua R. Farris and Charles Taliaferro (Surrey UK and Burlington America: Ashgate Publishing, 2015), 315.
} 
I will challenge this common view of teleology, argue against materialist reductions of purposive phenomena, and positively point towards the explanatory value of teleological categories for making sense of biological entities. The value of utilising "for-the-sake-oflanguage" becomes most clear in the resurgence of organismic thinking in developmental biology, which runs in contradictory course to monistic reductionism. From this I will also argue that because theosis stresses the teleological character of human becoming, it challenges the doctrine of mechanism and provides important theological insights regarding the epistemic limitations of the natural sciences.

The paper will proceed in three steps. First, I will outline the soteriological and eschatological content of theosis as it pertains to the God-human relationship, and the teleological entailment for the world on theosis. The next section will challenge the broadly reductionist attempt at making biology subordinate to chemistry and physics, and it will argue more positively for the ineliminability of teleology and the ways in which the conceptual return to organicism brings purposiveness back to biological discourses. The final section of this paper will briefly highlight the limitations of science in light of a theology that stresses the eschatological becoming of human nature and creation. It should be stressed that this paper does not argue that the recent turn towards organismic teleology proves a theosis-based theology. Rather, the overall argument is that Eastern Orthodoxy is a particularly well-suited metaphysic in which to welcome the return of organicism, and that this convergence points to the limitations of science.

\section{Theosis and human becoming}

The theological notion of theosis intends the deification of humans; the radical transformation of believers into the likeness of God. The idea of deification was important in the early church, even though it took some time until it became a broader label for the process of taking on God's character. ${ }^{3}$ The process, and core theme, of theosis has been expressed in a number of distinct ways and with regard to different strata of Christian theology. Origen placed deification on a Christological footing, suggesting that the deification of humanity is possible only because of the Christ-event, "God's prior humanization in Christ." ${ }^{\text {" Clement of }}$ Alexandria construed deification as maximum possible assimilation to God and the perfection of humans: “'Being baptized, we are illuminated; illuminated, we become sons; being made

\footnotetext{
${ }^{3}$ Stephen Finlan and Vladimir Kharlamov, "Introduction," in Theosis: Deification in Christian Theology, eds. Stephen Finlan and Vladimir Kharlamov (Cambridge, UK: James Clarke \& Co, 2006), 1.

${ }^{4}$ Michael J. Christensen, "The Promise, Process, and Problem of Theosis," 25.
} 
sons, we are made perfect; being made perfect, we are made immortal...", In the writings of Ignatius of Antioch we can see that deification is put in relation to the power of the Eucharist and the ecclesiastical unity of the Church. To participate in the Eucharist, according to Ignatius, is to be united with the Lord Jesus Christ through His blood. This process is summarised by Vladimir Kharlamov in the following way: "The collective unity of believers as the body of Christ, through the unity of the Eucharist and obedience to the bishop, is combined with the personal unity of each individual with God through Christ." ${ }^{\prime 6}$ In this way, the unification of the Church is linked up with the individual process of unification of each believer with God.

Theosis has a central place in Orthodox theology. In fact, deification is, as Andrew Louth helpfully remarks, not simply an optional add-on to the rest of the Orthodox theological system. It is not one part of a greater whole; rather deification is constitutive of the pattern of Eastern theology. Such pattern is "the mosaic...that emerges when the various doctrines of the faith are fitted together."7 Louth explains that deification, since about the twelfth century, is no longer a central part of the pattern of Western theologies. Over time, the notion of deification became marginalized and confined to mystic circles, consequently deemed theologically suspicious and even heretic. ${ }^{8}$ Nowadays the theological tides are turning, and much of recent scholarship on theosis is dedicated to retrieving the concept of deification, and various attempts have been made at putting it back into the "pattern" of Western Christendom. Scholars have, to name a few examples, explored the use and presence of deification/theosis in T.F Torrance's theological anthropology ${ }^{9}$, in Luther's Christology ${ }^{10}$, in Calvin's articulation of union ${ }^{11}$, in Catholic Theology ${ }^{12}$, and within Reformed theology as a

\footnotetext{
${ }^{5}$ Ibid.

${ }^{6}$ Vladimir Kharlamov, "Emergence of the Deification Theme in the Apostolic Fathers," in Theosis: Deification in Christian Theology, 64.

${ }^{7}$ Andrew Louth, "The Place of Theosis in Orthodox Theology," in Partakers of the Divine Nature, 33.

8 Ibid.

${ }^{9}$ See Myk Habet, Theosis in the Theology of Thomas Torrance (Surrey, UK and Burlington, USA: Ashgate, 2009).

${ }^{10}$ Tuomo Mannermaa, "Justification and Theosis in Lutheran-Orthodox Perspective," in Union with Christ: The New Finnish Interpretation of Luther, eds. Carl E. Braaten and Robert W. Jenson (Grand Rapids, MI and Cambridge, UK: Eerdmans, 1998), 25-41; Martin Linman, “Martin Luther: "'Little Christs for the World"”; Faith and Sacraments as Means to Theosis," in Partakers of the Divine Nature, 189-199; Bruce D. Marshall, "Justification as Declaration and Deification," International Journal of Systematic Theology 4 (2002): 3-28.

${ }^{11}$ See, in particular, Carl Mosser's excellent treatment of the eschatological goal of deification within Calvin's theology: Carl Mosser, "The greatest possible blessing: Calvin and deification," Scottish Journal of Theology 55 (2002): 36-57. Also, J. Todd Billings, "John Calvin: United to God Through Christ," in Partakers of the Divine Nature, 200-218.

12 A.N. Williams, The Ground of Union: deification in Aquinas and Palamas (New York: Oxford University Press, 1999); Daria E. Spezzano, The Glory of God's Grace: Deification According to St Thomas Aquinas (Florida: Sapientia Press of Ave Maria University, 2015).
} 
whole $^{13}$. Naturally, such theological interpretations and accommodation-attempts raise a number of critical issues and questions that go beyond the scope of this paper. ${ }^{14}$

A main contention of this paper is that theosis entails a robustly teleological conception of humanity. A great case study, in order to unpack this claim, is the soteriological vision of Maximus the Confessor, and in particular his distinction between tropos and logos - as primarily exemplified in Ambiguum 7. While logos represents the "metaphysical principles defining each specific nature", which owe their existence directly to the divine Logos, tropos designates the mode of existence for particular beings. ${ }^{15}$ Hence, deification consists in tropos aligning with logos, which is "the fulfilment of God's creational intent" for human creatures. ${ }^{16}$ It is this notion of tropos which allows Maximus to explain the fallenness of human beings and creation. Logoi remain intact, though human beings have turned their contemplation away from the divine being. That is, "they ceased to experience humanity in its fullness since in their tropoi (mode) of existence they lived at variance with the logos." ${ }^{17}$ Humanity is fragmented, and such fragmentation is caused by an attachment to the senses. ${ }^{18} \mathrm{By}$, firstly, repentance, and secondly, detachment, the soul is able to gradually move "towards integration. In practical life, virtues emerge, and through prayer or contemplation one's spiritual powers are united and directed to God."19 On Maximus's psychology, the soul has lost its integrity and hierarchical structure due to the wrong kind of union: a union with confusion. As Melchisedec Törönen goes on to explain: "If the parts are confused, they lose their wholeness, and as a consequence the entire soul loses its integrity." ${ }^{20}$ By detachment, the mind can engage in "natural contemplation" and see clearly the "natural logoi in beings without being distracted by their

\footnotetext{
${ }^{13}$ Gannon Murphy, "Reformed Theosis?" Theology Today 65 (2008): 191-212.

${ }^{14}$ Gösta Hallonsten has critically engaged with some recent scholarship regarding "theosis in the west". Hallonsten's main critique is that some scholars conflate the doctrine of theosis with themes related to theosis. While theosis-type language, argues Hallonsten, might show up in Western theologies, the doctrine of theosis encompasses "a certain view of creation, especially of human beings; a soteriology, including the meaning of the Incarnation; a view of Christian life as sanctification connected to the Church and sacraments; and the final goal of union with God." Gösta Hallonsten, "Theosis in Recent Research: A Renewal of Interest and a Need for Clarity," in Partakers of the Divine Nature, 285. Hallonsten concludes that current research on theosis, and the ambition to link up theosis with western theological doctrines, fails to take into account the robustly anthropological assumptions that the doctrine of deification so heavily rests on.

${ }^{15}$ Blackwell and Miller, "Theosis and Theological Anthropology," 305.

16 Ibid., 307.

17 Ibid., 308.

${ }^{18}$ See also Lars Thunberg's discussions regarding the causes of disintegration, which pertains to individual beings and humanity as a whole, and the positive relationship between virtues and re-integration. Lars Thunberg, Microcosm and Mediator: The Theological Anthropology of Maximus The Confessor (Chicago: Open Court Publishing: 1995), 231-330.

${ }^{19}$ Melchisedec Törönen, Union and Distinction in the Thought of St Maximus the Confessor (Oxford: Oxford University Press, 2007), 186.

${ }^{20}$ Ibid., 187.
} 
material usefulness..."21 The telos of each creature is inclined towards participation in God, yet "human beings turned their contemplation away from God and placed it on the created, sensible world." 22

Everything moves towards an end, and the movement towards God constitutes the ultimate end on Maximus's theological vision. ${ }^{23}$ According to Andreas Nordlander, "Logos is both the creative principle of all things and the telos toward which they move." ${ }^{24}$ All beings are called to realize their true telos, which for the Christian life is "to be consummated in deification..."25 On Maximus's vision, God has established a teleology of each being, and the telos of each being is to participate in God.

Participation in the divine life, according to Orthodox theology, is grounded in the Incarnation - God's initiative to meet us in human flesh - thus, through the Incarnation the final cause of humanity and physical reality is revealed to us. Deification, accordingly, "has to do with human destiny that finds its fulfilment in a face-to-face encounter with God..."26 Indeed, the very structure of theosis is, as Gösta Hallonsten notes, "determined by a teleology that implies that creation and human beings from the very beginning are endowed with an affinity and likeness that potentially draws them to God." ${ }^{27}$ Theosis is not, one should say, merely a descriptive term regarding increased closeness to or imitation of God, but normatively reveals the anthropological telos of human existence which is to experience salvation "in accordance with God's creational purpose." 28 Through the transfiguration and ontological transformation of human nature we can encounter God face to face, as expressed in $1 \mathrm{John}$ 3:2. This is not to claim that we become something other than human, that we leave the human condition behind completely. It is about the restoration of our true nature and our creaturely telos, the realization of full humanity. ${ }^{29}$ By Divine grace, human beings can rise above nature. Human nature, then, "is taken to extraordinary heights through a new, divine, mode of being which sustains the

\footnotetext{
21 Ibid., 188.

22 Blackwell and Miller, "Theosis and Theological Anthropology," 308.

${ }^{23}$ Andreas Nordlander, "Green Purpose: Teleology, Ecological Ethics, and the Recovery of Contemplation," Studies in Christian Ethics 00:0 (2020): 12.

24 Ibid., 13.

25 Ibid., 14.

${ }^{26}$ Andrew Louth, "The Place of Theosis in Orthodox Theology," in Partakers of the Divine Nature, 34.

27 Gösta Hallonsten, "Theosis in Recent Research: A Renewal of Interest and a Need for Clarity," 285.

${ }^{28}$ Blackwell and Miller, "Theosis and Theological Anthropology," 315.

${ }^{29}$ We encounter here a tricky problem. If human nature, as Jonathan Jacobs points out, literally changes then

"it would no longer be human nature." Jonathan Jacobs, "An Eastern Orthodox conception of theosis and human nature," Faith and Philosophy 26:5 (2009): 621. Jacobs proposes that we think of human nature in terms of a spectrum that each of us can fall short on. Union with God comes in degrees and so does our human nature.
} 
logos proper to created nature." 30 Participation in God cannot be reduced to a psychological thesis, but involves a real change, "a reconstitution of our humanity, a reshaping, a straightening out of all the distortions and corruptions that we have brought upon...our human capacities..." ${ }^{31}$ On Maximus's terminology, again, deification entails a real reintegration, restoration, and unification of the soul.

The purpose of humanity is, accordingly, intertwined and inseparable from the final goal of creation. On Orthodox theology, as we can see, the "teleology of creatures is thus intimately related to the doctrine of creation." 32 Theosis expresses a cosmic and eschatological dimension which brings together the biblical narrative of creation with human redemption. Louth describes this as a greater arch "stretching from creation to deification, representing what is and remains God's intention: the creation of the cosmos that, through humankind, is destined to share in the divine life, to be deified." 33 Humankind, as the "microcosm and bond of the cosmos", has a key role in the full participation of creation in the divine structure. ${ }^{34}$ God's eschatological plan is not limited to the deification of humanity. The doctrine of theosis sums up God's purpose for creation as a whole, which is the transformation of creation into a New Creation (Rom 8:14; 2 Pet 1:4). This eschatological reality means the full indwelling of God in creation and full participation and incorporation of creation into God's life. Hence, we encounter through the doctrine of deification, with its emphasis on the interconnectedness between the purpose of human creatures and creation, a teleological conception of nature; a groaning creation that is pulling towards communion and union with God. The doctrine of theosis invites us to appreciate reality through a teleological schema, which locates the end-goal of humanity and the wider cosmos in God's sovereign plan.

It is frequently claimed, however, that science rules out teleological phenomena and processes within nature. The idea is that Darwinism has replaced teleology with an observable, investigatable, and scientifically respectable mechanism: namely, natural selection. If true, such a turn to mechanism would render the theology of theosis, a core feature within Orthodox theology, at odds with the scientific community. I will challenge this

\footnotetext{
${ }^{30}$ Elena Vishnevskaya, "Divinization and Spiritual Progress in Maximus the Confessor," in Theosis: Deification in Christian Theology, eds. Stephen Finlan and Vladimir Kharlamov (Cambridge, UK: James Clarke \& Co, 2006), 137.

${ }^{31}$ Louth, "The Place of Theosis in Orthodox Theology," 37.

32 Nordlander, "Green Purpose," 14.

33 Louth, "The Place of Theosis in Orthodox Theology," 35.

${ }^{34}$ Ibid.
} 
pull towards teleological reductionism by exploring the positive value of teleology for making sense of nature.

\section{Why science cannot live without Teleology: Purpose in living systems}

Teleological concepts and notions are prevalent in every-day life and in many intellectual discourses. We often state that $X$ happens because of $Y$, that $W$ exists for the sake of $Z$, or that the purpose of $A$ is to produce $B$, and so on. Teleological categories, it seems, are indispensable and part and parcel of many human discourses, including the physical sciences, philosophy, ethics, and theology. Given the naturalness of teleology, who could seriously doubt the reality of it? Unfortunately, many do. Modern science, as Andrew Woodfield points out, "is on the whole hostile to teleological explanations. That they are obscurantist and unempirical has been the dominant view among scientists ever since the Renaissance." ${ }^{35}$ This shift can partly be explained by the expansion of mechanism from the realm of physics into the realm of biology. ${ }^{36}$

Immanuel Kant famously stated that "There will never be a Newton for the blade of grass." 37 The point of Kant's statement was that biology would never be able to explain living phenomena in terms of the non-living, that is mindless and purposeless "stuff". In physics you cite the relevant causal properties of, for example, velocity and mass with regard to specific physical phenomena. Biology, however, seemed to escape such physical reduction; thus, teleology was considered safe and irreducible. Biology lacked a strategy "for turning statements about purposes, goals, ends, and the means to achieve them into causal relations between earlier events and later ones they bring about." 38 This situation changed with Charles Darwin who proposed the mechanism of natural selection. What natural selection allowed the biologist to do was to connect the emergence of different organisms - and their specific capacities and traits - with their causal histories. On this new mechanistic framework, biological phenomena became causally explicable - in a similar vein to other physical objects and properties. Consequently, Darwin's theory allowed the sceptical naturalist to both rule out William Paley's Designer as the originator of teleology in the natural order, and to

\footnotetext{
${ }^{35}$ Andrew Woodfield, Teleology (Cambridge: Cambridge University Press, 1976), 3.

${ }^{36}$ Daniel J. Nicholson, "The concept of mechanism in biology," Studies in History and Philosophy of Biological and Biomedical Sciences 43:1 (2012): 152-163.

${ }^{37}$ Peter Schuster, "Is there a Newton of the blade of grass?: The Complex Relation Between Mathematics, Physics, and Biology," Complexity 16:5 (2011): 5.

${ }^{38}$ Alexander Rosenberg and Daniel W. McShea, Philosophy of Biology: A Contemporary Introduction (New York and London: Routledge, 2008), 15.
} 
causally reduce Aristotle's final causation to efficient causation. Darwin, as Ernest Haeckel concluded, became "the Newton of the grass blade". 39

Even though some have gained great confidence from Darwin's framework and believe now that teleology can be translated into non-teleological categories, the biological world seems rather resistant to such bold attempts. The biochemist Stuart Kauffman has done tremendous work on this issue, demonstrating why it is that the biological strata of nature seemingly defies reduction to the level of physics. ${ }^{40}$ Kauffman argues that this sort of reduction - famously associated with the philosophies of Laplace, Galileo, and Newton - is a mere pipe dream. Why? Because, due to the enormous complexity of the living world, we cannot "prestate the configuration space of a biosphere and, therefore, cannot deduce that which will unfold." ${ }^{41}$ Moreover, in order to predict the emergence of novelty, one needs to prestate all the possible selective environments; unfortunately, "we have not the faintest idea of what all possible selective environments might be." 42 This issue does not boil down to mere epistemology, but the emergence of novel entities in nature signifies something ontological about the irreducibility of biology. Indeed, given the emergent character of the biological world, "physics, in principle, cannot predict these unprestatable new functions". 43 Biology is the study of functions in the natural order and physics has, with its tools, no way of explicating biological functions or reducing such functions to purely physical language. Kauffman takes the human heart as an example. The physicist might be able to map out all the properties of the heart. Yet, she would have no way "whatsoever to pick out, from the entire set of the heart's properties, the pumping of blood as the causal feature that constitutes its function", the causal feature that accounts for its existence. ${ }^{44}$ Biological phenomena seemingly escape the reductionist grip.

Physics cannot capture the particularity of the biological. Yet, there are those who think that contemporary biology opens up for a higher-to-lower-level reductionism of a different sort, namely genetic reductionism. Alexander Rosenberg has made the bold claim that genetic

\footnotetext{
${ }^{39}$ Schuster, "Is there a Newton of the blade of grass?", 5.

${ }^{40}$ Stuart Kauffman has argued for this antireductionist conclusion in several influential works: Investigations (Oxford and New York: Oxford University Press, 2000); Reinventing the Sacred: A new View of Science, Reason, and Religion (New York: Basic Books, 2008); A World Beyond Physics: The Emergence and Evolution of Life (New York: Oxford University Press, 2019).

${ }^{41}$ Kauffman, Investigations, 113.

42 Kauffman, The Sacred, 132.

${ }^{43}$ Kauffman, Beyond Physics, 15.

${ }^{44}$ Kauffman, The Sacred, 34
} 
research can provide a complete explanation of biological development. ${ }^{45}$ In response to such a reductionist spirit, and the thesis of genetic primacy, Jason Scott Robert argues that genes are not the driving force of development: "genes play an important role, but as derived rather than driving factors". ${ }^{46}$ On a constitutive account, "epigenetics does not reduce to gene regulation, for genes themselves do not pre-exist developmental processes." ${ }^{47} \mathrm{We}$ cannot assume the genome as the natural starting point given that the genome, as Robert goes on to argue, does not precede the cell-organism. ${ }^{48}$ On this model, epigenetic structures result from - and so do not pre-exist - interactions in ontogenetic space and time. And, such interactions generate genes. This, as Robert concludes, renders the thesis of genetic primacy incoherent and vacuous. What makes the idea of genetic primacy even more unsustainable is the fact that any one genome can be realized in indefinite ways. ${ }^{49}$ According to John Duprè, the biological world exhibits a multitude of relational properties, and such properties are difficult to spell out in any causally linear fashion. Take, for example, a protein. A protein can catalyse many different reactions, and many proteins have multiple functions: they bind and transport various molecules, inhibit different cellular processes, and form subunits of larger proteins. In short, the "number of possible functions of a protein molecule seems, in principle, quite indefinite. $" 50$

The argument so far takes us from a view of evolution as determined by genetic factors to an "organism-centred biology" and "Postgenomic Darwinism". ${ }^{11}$ Organisms are not mere resultants of lower-level configurations, but they are causally efficacious and explanatorily relevant with regard to the evolutionary directionality of nature. Denis Walsch argues that the role of organisms - which was seen as highly relevant in the early days of biology - became marginalized due to the increased knowledge of genes and DNA. ${ }^{52}$ This new framework,

\footnotetext{
${ }^{45}$ Alexander Rosenberg, "Reductionism redux: Computing the embryo," Biology \& Philosophy 12 (1997): 445470.

${ }^{46}$ Jason Scott Robert, Embryology, Epigenesis, and Evolution (Cambridge: Cambridge University Press, 2004).

${ }^{47}$ Robert, Embryology, 74.

48 Ibid.

${ }^{49}$ Robert writes, "there is no one-to-one relationship between a particular genome and a particular phenotype; a single genome may be associated with any number of phenotypic variants, such that the phenotypic expression of a genome is the product of a system of epigenetic interactants coming together over a life cycle. Moreover, not only is the genome-phenotype relationship one to many, it is also many to one, as the same environmental conditions may generate the same phenotypes from different genomes." Embryology, 79.

50 John Duprè, "It is not Possible to Reduce Biological Explanations to Explanations in Chemistry and/or Physics," in Processes of Life: Essays in the Philosophy of Biology, ed. John Duprè (Oxford: Oxford University Press, 2012), 133.

${ }^{51}$ Scott, Embryology, 67; John Duprè, "Postgenomic Darwinism," in Processes of Life, 143-160.

52 See his, Organisms, Agency, and Evolution (Cambridge: Cambridge University Press, 2015).
} 
known as mechanism, could subsume the distinctive features of the living world. Yet, as we've seen thus far, mechanistic reductionism as manifested in the thesis of genetic priority is strikingly difficult to make empirical sense of. This situation has sparked the return of organicism among biological thinkers. ${ }^{53}$

Walsch singles out three distinctive contributions of organisms to biological evolution. (1) The production of novelties is made possible by the plasticity of organisms - meaning that they respond efficaciously to changing environmental conditions. ${ }^{54}$ Moreover, it is this ability of the organism to respond in survival-conducive ways that help us to explain "the origin and maintenance of novel phenotypic characters in evolution." 55 As Walsch puts it, "Evolution is adaptive, because organisms are adaptive, goal-directed systems." ${ }^{56}$ (2) The high fidelity of phenotypic inheritances, as is becoming increasingly clear, is due to the goal-directed capacities of organisms, in particular the capacity to "detect, respond to and repair DNA lesions", and the developmental system's general reliability to "produce inheritable phenotypes across an enormous range of genetic and environmental variations." ${ }^{, 57}$ (3) According to Walsch and others, we are now slowly abandoning the view of the gene as an individual unit in favour of a "conception of the genome as highly integrated, goaldirected...", capable of drawing on a variety of resources in order to further an organism's development. $^{58}$

As seen from this portrayal of the nature, activities, and contributions of organismic systems, goal-directedness is part and parcel of the biological world. Organisms are teleological entities, and such entities cannot be reduced to the lower levels of chemistry and physics, nor can they be easily accommodated within a materialist schema. It is within the structure and organizational behaviour of the organism that we see teleology most clearly.

\footnotetext{
53 See Walsch, Organisms; Peter A. Corning, "Evolution 'on purpose': how behaviour has shaped the evolutionary process," Biological Journal of the Linnean Society 112 (2014): 242-260; Philip Clayton, "Machines and Organisms: The Rise and Fall of a Conflict," in Beyond Mechanism: Putting Life Back into Biology, eds. Brian G. Henning and Adam C. Scarfe (Plymouth: Lexington Books, 2013); Paul Guyer, "Organisms and the Unity of Science," in Kant and the Sciences, ed. Eric Watkins (New York: Oxford University Press, 2001); Mary Jane West-Eberhard, "Developmental plasticity and the origin of species differences," Proceedings of the National Academy of Sciences of the United States of America 102 (2005): 6543-6549; Mary Jane West-Eberhard, Developmental Plasticity and Evolution (New York: Oxford University Press, 2003); Matteo Mossio and Leonardo Bich, "What makes biological organisation teleological?," Synthese 194 (2017): 1089-1114. Richard Lewontin, The Triple Helix: Gene, Organism, and the Environment (Cambridge, MA: Harvard University Press, 2000); Scott F. Gilbert and Sahotra Sarkar, "Embracing complexity: Organicism for the $21^{\text {st }}$ century," Developmental Dynamics 219 (2000): 1-9.

${ }^{54}$ Walsch, Organisms, 203.

55 Ibid.

56 Ibid.

57 Ibid., 204.

58 Ibid., 205.
} 
The organism is intrinsically teleological, as Georg Toepfer has argued. The biological concept of an organism only makes sense from a teleological standpoint. The definition of the "organism is based on teleological reasoning because identifying organisms as a special kind of natural systems includes the attribution of functions or purposes to their parts." ${ }^{, 59} \mathrm{In}$ studying the functionality of organisms, we are analysing the causal processes in terms of the end-states of those processes. ${ }^{60}$ This also means that teleology plays an essential methodological role within the biological sciences by providing "a descriptive tool for analyzing systems in terms of their functional components and thereby enabling a proper conceptualization of them." ${ }^{61}$ Hence, a teleological analysis provides a criterion for identifying organized systems. However, such analysis is not simply a mode of explanatory reasoning, it is more importantly what enables biologists to, as Toepfer puts it, "come to terms with their objects." ${ }^{62}$ Teleology is "what makes biology a special science." 63 The possibility of ascribing purposes, functions, and end-states to organized systems is vital for biology as a science - thus, teleology plays an essential role for the practice of the biological sciences.

\section{Teleology, Theosis, and the Limitations of Science}

On Eastern Orthodoxy, human beings and the whole of creation are situated eschatologically. The destiny of both humanity and creation is to share in the divine life, becoming partakers of the divine nature. Theosis is an articulation of God's original intention for humans and creation, and it offers a view of redemption as interconnected with union and participation. ${ }^{64}$ As I argued earlier, theosis entails a teleological conception of humanity and nature which puts it in direct opposition to the doctrine of mechanism. A main ambition with this paper has been to challenge a mechanistic dismissal of purpose within creation and an anti-teleological view of nature's becoming. I have sketched several reasons for why a whole-scale reduction of the realm of biology to the lower levels of physical reality is unfeasible. The biological realm produces novel entities which are unpredictable from their lower-level base structures and, thus, such emergent events make a biology-to-physics reduction rather implausible.

\footnotetext{
${ }^{59}$ Georg Toepfer, "Teleology and its constitutive role for biology as the science of organized systems in nature," Studies in History and Philosophy of Biological and Biomedical Sciences 43 (2012): 113-119.

60 Ibid., 115.

61 Ibid., 116.

62 Ibid., 114.

63 lbid.

${ }^{64}$ Blackwell and Miller, "Theosis and Theological Anthropology," 315.
} 
Equally problematic is the ambition to resurrect a reductionist vision of biology based on contemporary genetic research. Rather than confirming a broader mechanistic vision of evolution, the functionality of genetic structures seems to confirm the reality of enddirectedness in nature given that genomes themselves engage in "for-the-sake-of" process cycles.

As reductionism is losing force, there has been a cautious shift from mechanism to organism within the biological community. An organism-centred biology conceives organisms as agential and teleological participators in the evolutionary process; not simply passive resultants or by-products of physical configurations. Teleological reasoning is, therefore, crucial for the continuous functioning of the biological sciences.

This picture coheres well with an Eastern Orthodox emphasis on purpose for and within creation. Teleology is not to be explained away in terms of efficient causation - which is the required philosophical move on materialism - but is to be expected given the purposive activity of a creator God. Hence, "our existence is not due entirely to chance and randomness. Cosmic and biological evolution is not aimless." ${ }^{65}$ Theosis provides an expansive ontology and can therefore more easily accommodate teleological phenomena.

Before bringing out the implications of an Eastern Orthodox metaphysics for science, I want to add some qualifiers. My aim has been to draw attention to a possible convergence between the doctrine of theosis and an emerging, teleology-friendly collection of theories within the biological community. At this point, however, it is worth emphasising those theological and philosophical issues that fall beyond the scope of this paper.

Firstly, this exploration has not addressed the relationship between God as the one who enables deification, and humans participating in theosis by free will; thus realizing their true telos. For "human beings this crucially involves the free choice to live in the direction of their true telos" which is to participate in God's being. ${ }^{66}$ At the same time, Orthodox theology stresses that deification is ultimately a gift from God, and we become partakers in the divine by grace. This paper does not shed light on the complex metaphysical relationship between God's sovereignty and providence, and the free will of human beings. The Orthodox stance stresses clearly that "deification is wholly a gift of God and is not attainable by nature's nude powers." ${ }^{67}$ Although human creatures possess the desire to realize their true telos, the process

\footnotetext{
65 Mikael Stenmark, “Theories of Human Nature: Key Issues," Philosophy Compass 7:8 (2012): 551.

${ }^{66}$ Nordlander, "Green Purpose," 14.

${ }^{67}$ Polycarp Sherwood, The Earlier Ambigua of Saint Maximus the Confessor and His Refutation of Origenism (Rome: Orbis Catholicus Herder, 1955), 71.
} 
of deification cannot be reduced to human agency and willpower, but must be grounded firmly in the divine intention for creation and human beings.

Secondly, but closely related to the first issue, a theosis-based anthropology pictures an intimate relation between human purposiveness and God as the ground of purpose. The Logos of each being signifies the reality of intrinsic teleology; that is, "goal-orientated behaviour which belongs to something by virtue of what it is." $" 68$ God is, however, at the same time the extrinsic, or ultimate, cause of the teleological structure of human creatures, and has endowed beings with the desire towards theosis. Can we, then, coherently hold together these two assertions, or might intrinsic teleology be bought at the expense of extrinsic teleology? ${ }^{69}$ This paper does not purport to answer this issue. It is, however, worth mentioning a couple of responses and ways of navigating beyond a dualistic and dichotomous standing between intrinsic and extrinsic teleology. Andreas Nordlander helpfully explains, in his exploration of Maximus's theosis, that the opposition between these two teleologies is a false one. God does not "impose" the "logos-structure" on creatures. Rather, "creatures exist and are properly themselves through their logoi, which pre-existed in the divine Logos before being" created. ${ }^{70}$ Hence, God does not extrinsically impose telos on creatures, but creatures participate in God's being, and possess intrinsic teleology because of this participation.

From the perspective of autopoietic biology, Simon Oliver has called into question the often-assumed dualism between intrinsic and extrinsic teleology on the basis that an organism's self-making carries an extrinsic orientation or directedness towards a specific environment. To put this in other words, in order to make sense of the teleological behaviour of organisms, we must situate these features in particular environments and biological/physical contexts. ${ }^{71}$ The boundary, then, between intrinsic and extrinsic teleology is fluid, and we need to employ one to understand the other.

With the stated two qualifications in mind, let us now focus on the ways in which theosis, by situating humanity in relation to the eschatological activity of God, brings into the picture a well-needed realism regarding the epistemic limitations of science. ${ }^{72}$ An eschatological account of human nature is clear about the fact that "the fulfilment of our created being is

\footnotetext{
${ }^{68}$ Simon Oliver, "Teleology Revived? Cooperation and the Ends of Nature," Studies in Christian Ethics 26 (2013): 158-165.

${ }^{69}$ I discuss this issue in a forthcoming paper. See Mikael Leidenhag, "Purpose for and within Creation: A Theological Appraisal of Organismic Teleology," Modern Theology.

70 Nordlander, "Green Purpose," 14.

71 Oliver, "Teleology Revived," 164.

72 This is not to claim that Eastern Orthodoxy is anti-scientific; not at all. But it reveals a deep problem with thinking that science holds the only epistemic key for capturing the essence of human personhood.
} 
found in corresponding to the creator's orientation toward us by our being unconditionally faithful to God and to others. We are created for communion with God and one another - and that communion defines our natures." $" 73$ At the same time, it should be strongly noted that theosis does not call for any kind of simplistic dismissal of the value of science for understanding human nature, the evolutionary origins of it, or the structure of human capacities. It instead encourages a general expansion of the scientific image, its view of nature and what it is that makes us human. To state that science is limited when it comes to human nature is, in my regard, rather uncontroversial. Evolution is,

"essentially focused on the present and attempts to delineate laws according to which the present emerged from the past. Developmental theories are past orientated, trying to discern the causal relationship of organisms in the present world. They do not make any assertions about the end and goal of this world or about the laws and conditions in a future aeon. Therefore they do not contribute anything to our knowledge of the last things.",74

While evolution can deliver valuable insights regarding human nature, it can from a theological standpoint not offer a sufficient account of what it is that makes us human and how to understand our place in the grand scheme of things. This should land us in the conclusion that "to conceive of the human being outside of its relation to God is not a neutral option." 75 Theosis delivers us the valuable insight that what we are is intimately connected with what we will become. ${ }^{76}$

\footnotetext{
${ }^{73}$ Alan Torrance, "Is There a Distinctive Human Nature? Approaching the Question from a Christian Epistemic Base," Zygon: Journal of Religion and Science 47 (2012): 908.

${ }^{74}$ Hans Schwarz, Eschatology (Grand Rapids, MA and Cambridge, UK: William B. Eerdmans Publishing Company, 2000), 185-186.

75 Torrance, "Is There a Distinctive Human Nature?" 907. Torrance does not make this argument on the basis of theosis, but rather a general view of the believer's participation in Christ.

${ }^{76}$ This publication has been made possible by the project, Science and Orthodoxy Around the World. I would like to thank two anonymous reviewers for their many helpful remarks and suggestions.
} 